\title{
Blood Cd levels and carotid intima-media thickness in young adults living in Padang, Indonesia
}

Cimi Ilmiawati ${ }^{1,5^{*}} \mathbb{B}$, Mohamad Reza ${ }^{2}$, Mefri Yanni $^{3}$ and Dina Arfiani Rusjdi ${ }^{4}$

\begin{abstract}
Objective: Cd exposure is a non-traditional risk factor of cardiovascular disease and mortality by promoting the development of atherosclerosis. The development of atherosclerosis can be monitored non-invasively by measuring carotid intima-media thickness (CIMT). This study aimed to measure the level of blood $\mathrm{Cd}$ and other factors known to be associated with CIMT, measured at the segment of common carotid artery (CCA) and of internal carotid artery (ICA), in young adults from Padang, West Sumatera, Indonesia, and we analyzed whether blood Cd is a predictor of CIMT.

Results: We recruited 156 subjects. Median blood Cd level was $0.61 \mu \mathrm{g} / \mathrm{L}$ (range $0.01-5.96 \mu \mathrm{g} / \mathrm{L}$ ), with no difference in male compared to female subjects (Mann-Whitney $U$ test, $p=0.60$ ). Multiple regression analysis showed that sex is the predictor of CCA IMT (adjusted $\mathrm{R}^{2}=0.219 ; \beta=-0.438[95 \% \mathrm{Cl}-0.662,-0.214] ; \mathrm{p}<0.001$ ) and ICA IMT (adjusted $R^{2}=0.165 ; \beta=-0.529[95 \% \mathrm{Cl}-0.761,-0.297] ; p<0.001$ ). Blood Cd was not a predictor of CCA IMT (adjusted $R^{2}=0.219 ; \beta=-0.101[95 \% \mathrm{Cl}-0.257,0.055] ; p=0.203$ ) and ICA IMT (adjusted $R^{2}=0.165 ; \beta=-0.055[95 \% \mathrm{Cl}$ $-0.217,0.107] ; p=0.503$ ) in young adults from Padang, Indonesia.
\end{abstract}

Keywords: Atherosclerosis, Cadmium, Carotid, Indonesia, Intima-medial thickness, Young adults

\section{Introduction}

Extensive use of cadmium $(\mathrm{Cd})$ in multitude industries and consumer products are the source of environmental exposure to $\mathrm{Cd}[1]$. $\mathrm{Cd}$ as a toxic metal is known to have promoting effects on murine and human atherosclerosis $[2,3]$ and epidemiological studies show that blood $\mathrm{Cd}$ is associated with the risk and incident of cardiovascular disease (CVD) and mortality [4-6]. Most of the risk factor for CVD are modifiable, therefore preventable. Environmental risk factors work through initiation or promotion of pathophysiological process associated with CVD. Despite having smaller contribution as risk factors

\footnotetext{
*Correspondence: ilmiawati@med.unand.ac.id; dr.ilmiawati@gmail.com ${ }^{5}$ Division of Environmental Toxicology, Department of Pharmacology, Faculty of Medicine, Andalas University, Main Campus at Limau Manis, Gedung A Lantai 1, Pauh, Padang, West Sumatra 25166, Indonesia Full list of author information is available at the end of the article
}

compare to traditional risk factors, environmental risk factors become substantial when the number of populations exposed is large [7]. Research within the last decade have shown that exposure to environmental pollutant, like air pollution and toxic metals (cadmium, lead, arsenic) contributes to the development and severity of CVD [8].

Epidemiological studies have shown that blood Cd level is associated with the incident and mortality of CVD in Swedish population [4]. Blood Cd is associated with CVD risk in Korean men [5] and with carotid plaque prevalence in Swedish population [9]. Cd content of carotid plaque was found to be 50 times of that in blood and $\mathrm{Cd}$ exposure was correlated with subclinical atherosclerosis in middle age women from Swedia [10].

Atherosclerosis is a slow but progressive vascular change beginning at young age and plays an important

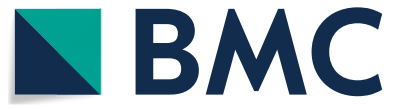

(c) The Author(s) 2020. This article is licensed under a Creative Commons Attribution 4.0 International License, which permits use, sharing, adaptation, distribution and reproduction in any medium or format, as long as you give appropriate credit to the original author(s) and the source, provide a link to the Creative Commons licence, and indicate if changes were made. The images or other third party material in this article are included in the article's Creative Commons licence, unless indicated otherwise in a credit line to the material. If material is not included in the article's Creative Commons licence and your intended use is not permitted by statutory regulation or exceeds the permitted use, you will need to obtain permission directly from the copyright holder. To view a copy of this licence, visit http://creativeco mmons.org/licenses/by/4.0/. The Creative Commons Public Domain Dedication waiver (http://creativecommons.org/publicdomain/ zero/1.0/) applies to the data made available in this article, unless otherwise stated in a credit line to the data. 
role in the pathogenesis of CVD, including hypertension, ischemic heart disease, peripheral arterial disease and stroke [11], the number one killer in developing country [12]. The development of atherosclerosis can be monitored by non-invasive method by measuring the intimamedia thickness (IMT) of major superficial arteries, like carotid and femoral arteries.

There are many studies showings that environmental $\mathrm{Cd}$ exposure is associated with atherosclerosis in developed countries, however there is still limited studies in developing countries. Considering high CVD prevalence and different pattern of environmental pollutant exposure in Indonesia as a developing country compared to those of developed country, it is essential to conduct a $\mathrm{Cd}$ biomonitoring study in young adults from Indonesia. In the current study, we measured the level of blood $\mathrm{Cd}$ and other factors known to be associated with carotid intimamedia thickness (CIMT) in young adults from Padang, West Sumatera, Indonesia, and we analyzed whether blood Cd is a predictor of CIMT.

\section{Main text \\ Subjects and methods Study subjects}

The participants were 156 young adults, enrolled as university students, aged 18-24 living in Padang, West Sumatera, Indonesia. Subjects were invited through the student's body organization to participate in the group health examinations for the investigation of cadmium exposure as a vascular toxicant. Subjects with history of cardiovascular disease were excluded. All subjects signed the appropriate informed consent. The study was approved by the Ethics Committee of Faculty of Medicine Andalas University (No. 350/KEP/FK/2018) and was conducted in line with the Declaration of Helsinki.

\section{Cd determination in blood samples}

Blood Cd was analyzed by Prodia Industrial Toxicology Laboratory (Jakarta, Indonesia) using Agilent 7700 inductively coupled plasma-mass spectrometry (ICPMS). Blood Cd was analyzed from whole blood sample according to the method by CDC (CDC, 2011) with some modifications. The limit of detection (LOD) for $\mathrm{Cd}$ in blood was $0.004 \mu \mathrm{g} / \mathrm{L}$ and the limit of quantification (LOQ) was $0.015 \mu \mathrm{g} / \mathrm{L}$. No sample was below LOQ. The level of analytical accuracy was $84.2-89.8 \%$ and the level of analytical precision was $7.8-8.7 \%$.

\section{Measurement of blood pressure}

Systolic and diastolic blood pressures were measured with a digital monitor (Omron HEM-7120, Japan). Subjects were seated for five minutes before the measurement began. Blood pressure were taken three times, the average value of the last two measurements were used for analysis [13]. No regular use of antihypertensive drugs was reported. Hypertension was defined as systolic blood pressure $\geq 130 \mathrm{mmHg}$ and diastolic blood pressure $\geq 80 \mathrm{mmHg}$ [14].

\section{Measurement of CIMT}

CIMT of common carotid artery (CCA) and internal carotid artery (ICA) was measured by ultrasonography of the left and right carotid artery according to the published method [15]. CIMT measurement was available for all subjects.

\section{Laboratory methods}

Blood samples were drawn in non-fasting subjects and glucose, hemoglobin $(\mathrm{Hb})$, triglycerides, total cholesterol, low-density lipoprotein cholesterol (LDL-cholesterol), and high-density lipoprotein cholesterol (HDL-cholesterol) were determined by standard methods. Cd bioavailability is affected by low iron status [16], therefore we determined $\mathrm{Hb}$ level in our subjects. Non-fasting blood glucose was measured in sera using enzymatic photometric test (DiaSys, Germany). All analyses were carried out at the Biochemistry Laboratory of Faculty of Medicine Andalas University.

\section{Covariates}

Factors potentially affecting CIMT included in statistical analyses were: (1) Age; (2) Sex; (3) Body mass index (BMI); (4) Parental education; (5) Exposure to cigarette smoke; (6) Systolic blood pressure; (7) Serum total cholesterol; (8) Serum HDL-cholesterol; (9) Haemoglobin; and (10) Blood glucose level. Body weight and height were measured to the nearest $0.1 \mathrm{~kg}$ and $0.1 \mathrm{~cm}$, respectively, with subject wearing light clothing and no shoes. BMI was calculated as body weight $(\mathrm{kg})$ divided by square of body height $\left(\mathrm{m}^{2}\right)$.

Age (in year), smoking habit (never, former, current), secondhand smoking exposure (never, sometimes, frequently, always), alcohol intake (yes or no), parental education (without college education, college education, postgraduate education), parental monthly income $(<3$, $310,>10$ million Indonesian rupiah), residence close to a metal workshop or industry (yes or no) were obtained from an 2-page questionnaire.

\section{Statistical analysis}

The distribution of blood $\mathrm{Cd}$ is not normal and therefore expressed in median, interquartile range, and range. Student's t-tests were performed to compare blood pressure, serum lipids, blood glucose and hemoglobin levels, while Mann-Whitney U test was performed to compare blood $\mathrm{Cd}$ between sexes. Blood Cd was natural log transformed 
before included in the regression analyses. Multiple regression analyses were performed to identify predictors of CIMT. Statistical significance was considered at a $p$ value $<0.05$. IBM SPSS statistical software version 25.0 (IBM, US) was used for the analyses.

\section{Results}

\section{Characteristics of subjects}

Detailed characteristics of the subjects are presented in Table 1. Our subjects were mostly normoweight (42.3\%), never smoked (72.4\%), non-drinker (98.7\%), exposed to secondhand smoke (97.4\%) young adults living in Padang, a coastal city as the capital of West Sumatera Province, Indonesia. Parental education, monthly income, and location of residence related to industry were also presented.

\section{Blood pressure, $\mathrm{Hb}$, blood glucose, serum lipids, blood Cd and CIMT}

Descriptive statistics of systolic and diastolic blood pressure, $\mathrm{Hb}$, blood glucose, serum lipids, blood $\mathrm{Cd}$, and CIMT are presented in Table 2. Male subjects showed statistically significantly higher systolic blood pressure and $\mathrm{Hb}$ levels compared to female subjects $(\mathrm{p}<0.001)$. There were no differences in diastolic blood pressure, blood glucose, total cholesterol, HDL-cholesterol, and LDL-cholesterol levels between sexes. Blood Cd level in young adults of Padang is shown in Table 2 with further comparison between sexes. The median of blood $\mathrm{Cd}$ in all subjects was $0.61 \mu \mathrm{g} / \mathrm{L}$ with no statistically significant difference between sexes $(p=0.60)$. The range of blood $\mathrm{Cd}$ value was $0.01-5.96 \mu \mathrm{g} / \mathrm{L}$. No sample was below the LOQ. CIMT of CCA and ICA were found to be statistically significantly thicker in male compared to female subjects $(\mathrm{p}<0.001$; Table 2$)$.

\section{Predictors of CIMT}

To identify factors associated with CIMT, we performed a multiple regression with blood $\mathrm{Cd}$ adjusted for age and sex only (Additional file 1: Table S1), and then we carried out a multivariable model including all relevant variables and blood Cd (Table 3). Our model predicted $21.9 \%$ variation in CCA IMT, with sex as the best predictor $(\beta=-0.438$ [95\% confidence interval $(\mathrm{CI})-0.662$, -0.214 ]; $\mathrm{p}<0.001)$. The model for predicting ICA IMT, where $16.5 \%$ variation is accounted for, showed that sex was the best predictor $(\beta=-0.529$ [95\% CI -0.761 , -0.297 ]; $\mathrm{p}<0.001)$. Blood Cd was not a predictor of CCA IMT (adjusted $\mathrm{R}^{2}=0.219 ; \beta=-0.101$ [95\% CI -0.257 , $0.055] ; \mathrm{p}=0.203$ ) and ICA IMT (adjusted $\mathrm{R}^{2}=0.165$; $\beta=-0.055$ [95\% CI $-0.217,0.107] ; p=0.503)$.

\section{Discussion}

Our study of blood Cd levels in Indonesian young adults living in a coastal city of Padang in West Sumatera Province showed that the median blood Cd levels $(0.61 \mu \mathrm{g} / \mathrm{L})$ is quite low compared to a previous study in adolescents in Iran ( $10 \mu \mathrm{g} / \mathrm{L}$ (mean); [17]). However, this level was higher than that of 9-10-year-old children in Japan $(0.34 \mu \mathrm{g} / \mathrm{L}$ (geometric mean); [18]) and $20-34$ year-old general population in the US $(0.27 \mu \mathrm{g} / \mathrm{L}$ (geometric mean); [19]). The median of blood Cd in our female subjects is lower than that of 18-24-year-old Norwegian women (0.59 vs. $1.43 \mu \mathrm{g} / \mathrm{L} ;[20])$.

Our finding in this small study showed that most subjects are exposed to secondhand smoke. A single cigarette is estimated to contain $12 \mu \mathrm{g}$ of $\mathrm{Cd}$, an average of $10 \%$ is inhaled during smoking [21]. With no known elimination pathway, $\mathrm{Cd}$ will accumulate in various tissues, mostly in liver and kidneys [22], and also in aorta [23]. With continuous exposure to cigarettes smoking, our subjects may accumulate higher $\mathrm{Cd}$; hence elevates the risk of adverse health effects. Educational measures on smoking prevention and/or avoiding environmental tobacco smoke should be instigated in young adults and the general population.

Quantitative measurement of intima-medial thickness of large superficial arteries, like carotid and femoral arteries, by using B-mode ultrasonography (USG) is a non-invasive, fast, safe, and highly reproducible method to assess individual CVD risk [24]. Epidemiological studies showed that CIMT is a marker of subclinical atherosclerosis and is associated with conventional risk factors of CVD. CIMT calculation is the most widely used non-invasive atherosclerosis assessment by clinicians and clinical investigators [25].

Carotid artery is elastic and, in healthy young subjects, CIMT consists almost all of medial layer. Normal carotid arterial wall is not influenced by age or sex until around 18 years old; after 18 years, diffuse and progressive thickening takes place in intimal layer [26]. Our subjects' age ranges from 18 to 24 -year-old and it is possible that early process of atherosclerosis has taken place in their arteries. We find that CIMT of male subjects is higher than female subjects and this is in line with the available evidence [27]. A previous study in a cohort of young adults aged 27 to 30 years in Netherland found that marked increased in CCA IMT is associated with unfavorable profile of cardiovascular risk [15]. In this study, we found that sex, rather than blood $\mathrm{Cd}$, as the predictor of CIMT. This might be explained by the relatively low levels of blood $\mathrm{Cd}$ in our subjects. Furthermore, considering the relatively young age of our participants, atherosclerosis might have not significantly developed to contribute to CIMT. 
Table 1 Characteristics of participants $(n=156)$

\begin{tabular}{|c|c|c|c|c|}
\hline & \multirow[t]{2}{*}{ All } & \multicolumn{3}{|l|}{ Cd tertile } \\
\hline & & $1(n=52)$ & $2(n=52)$ & $3(n=52)$ \\
\hline \multicolumn{5}{|l|}{$\operatorname{Sex}(n,(\%))$} \\
\hline Male & $85(54.5)$ & $28(53.8)$ & $23(44.2)$ & $34(65.4)$ \\
\hline Female & $71(45.5)$ & $24(46.2)$ & $29(55.8)$ & $8(34.6)$ \\
\hline \multicolumn{5}{|l|}{ Age (years) } \\
\hline Mean (SD) & $20.7(1.4)$ & $20.5(1.2)$ & $20.8(1.3)$ & $20.9(1.6)$ \\
\hline Range & $18-24$ & & & \\
\hline \multicolumn{5}{|l|}{ BMI (n, (\%)) } \\
\hline \multicolumn{5}{|l|}{ Underweight } \\
\hline $\begin{array}{l}(<18.5 \mathrm{~kg} / \\
\left.\mathrm{m}^{2}\right)\end{array}$ & $22(14.1)$ & $6(11.5)$ & $7(13.5)$ & $9(17.3)$ \\
\hline \multicolumn{5}{|l|}{ Normoweight } \\
\hline $\begin{array}{c}(18.5-22.9 \\
\left.\mathrm{kg} / \mathrm{m}^{2}\right)\end{array}$ & $66(42.3)$ & $21(40.4)$ & $20(38.5)$ & $25(48.1)$ \\
\hline \multicolumn{5}{|l|}{ Overweight } \\
\hline $\begin{array}{c}(23.0-24.9 \\
\left.\mathrm{kg} / \mathrm{m}^{2}\right)\end{array}$ & $28(17.9)$ & $12(23.1)$ & $10(19.2)$ & $6(11.5)$ \\
\hline \multicolumn{5}{|l|}{ Obese } \\
\hline $\begin{array}{l}(>24.9 \mathrm{~kg} / \\
\left.\mathrm{m}^{2}\right)\end{array}$ & $40(25.6)$ & $13(25.0)$ & $15(28.8)$ & $12(23.1)$ \\
\hline \multicolumn{5}{|c|}{ Smoking habit (n, (\%)) } \\
\hline Never & $113(72.4)$ & 44 (84.6) & $45(86.5)$ & $24(46.2)$ \\
\hline Former & $12(7.7)$ & $4(7.7)$ & $4(7.7)$ & $4(7.7)$ \\
\hline Current & $31(19.9)$ & $4(7.7)$ & $3(5.8)$ & $24(46.2)$ \\
\hline \multicolumn{5}{|c|}{ Secondhand smoking exposure $(\mathrm{n},(\%))$} \\
\hline Never & $4(2.6)$ & $1(1.9)$ & $2(3.8)$ & $1(1.9)$ \\
\hline Sometimes & $\begin{array}{l}81 \\
(51.9)\end{array}$ & $36(69.2)$ & $28(53.8)$ & $17(32.7)$ \\
\hline Frequently & $51(32.7)$ & $12(23.1)$ & $20(38.5)$ & $19(36.5)$ \\
\hline Always & $20(12.8)$ & $3(5.8)$ & $2(3.8)$ & $15(28.8)$ \\
\hline \multicolumn{5}{|c|}{ Alcohol intake (n, (\%)) } \\
\hline Yes & $2(1.3)$ & - & - & $2(3.8)$ \\
\hline No & $154(98.7)$ & $52(100)$ & $52(100)$ & $50(96.2)$ \\
\hline \multicolumn{5}{|c|}{ Parental education (n, (\%)) } \\
\hline $\begin{array}{l}\text { Without col- } \\
\text { lege educa- } \\
\text { tion }\end{array}$ & $56(35.9)$ & $14(26.9)$ & $21(40.4)$ & $21(40.4)$ \\
\hline $\begin{array}{l}\text { College educa- } \\
\text { tion }\end{array}$ & $68(43.6)$ & $29(55.8)$ & $19(36.5)$ & $20(38.5)$ \\
\hline $\begin{array}{l}\text { Postgraduate } \\
\text { education }\end{array}$ & $32(20.5)$ & $9(17.3)$ & $12(23.1)$ & $11(21.2)$ \\
\hline \multicolumn{5}{|c|}{ Parental monthly income $(\mathrm{n},(\%))$} \\
\hline$<3$ million IDR & $49(31.4)$ & $14(26.9)$ & $17(32.7)$ & $18(34.6)$ \\
\hline $\begin{array}{l}\text { 3-10 million } \\
\text { IDR }\end{array}$ & $91(58.3)$ & $30(57.7)$ & $33(63.5)$ & $28(53.8)$ \\
\hline $\begin{array}{l}>10 \text { million } \\
\text { IDR }\end{array}$ & $16(10.3)$ & $8(15.4)$ & $2(3.8)$ & $6(11.5)$ \\
\hline \multicolumn{5}{|c|}{ Residence close to metal workshop or industry $(n,(\%))$} \\
\hline Yes & $23(14.7)$ & $11(21.2)$ & $7(13.5)$ & $5(9.6)$ \\
\hline No & $133(85.3)$ & $41(78.8)$ & $45(86.5)$ & $47(90.4)$ \\
\hline
\end{tabular}

$S D=$ standard deviation, $B M I=$ body mass index $I D R=$ Indonesian Rupiah 
Table 2 Blood pressure and concentration of haemoglobin, blood glucose, serum lipids, blood Cd and CIMT of young adults from Padang

\begin{tabular}{|c|c|c|c|c|c|c|c|c|c|}
\hline \multirow[t]{2}{*}{ Variable } & \multicolumn{4}{|l|}{ All $(n=156)$} & \multicolumn{2}{|l|}{ Male $(n=85)$} & \multicolumn{2}{|c|}{ Female $(n=71)$} & \multirow[t]{2}{*}{ p-value ${ }^{\#}$} \\
\hline & Mean (SD) & Median (IQR) & Min & Max & Mean (SD) & Median (IQR) & Mean (SD) & Median (IQR) & \\
\hline $\begin{array}{l}\text { Systolic blood pressure } \\
(\mathrm{mmHg})\end{array}$ & $115.1(14.7)$ & & 80 & 167 & $122.8(12.9)$ & & $105.8(10.6)$ & & $<0.001$ \\
\hline $\begin{array}{l}\text { Diastolic blood pressure } \\
(\mathrm{mmHg})\end{array}$ & $71.1(9.4)$ & & 45 & 107.5 & $72.4(10.2)$ & & $69.4(8.2)$ & & 0.04 \\
\hline Hemoglobin (g/dL) & $14.4(2.3)$ & & 9.1 & 18.2 & $15.7(1.8)$ & & $12.8(1.7)$ & & $<0.001$ \\
\hline Blood glucose (mg/dL) & $78.5(8.6)$ & & 55.4 & 97.4 & $80.3(8.4)$ & & $76.5(8.4)$ & & 0.01 \\
\hline Total cholesterol (mg/dL) & $165.8(29.5)$ & & 82.2 & 267.1 & $166.2(29.1)$ & & $165.4(30)$ & & 0.88 \\
\hline HDL-cholesterol (mg/dL) & $70.9(22.7)$ & & 31.1 & 173.7 & $71.6(21.6)$ & & $70.1(24.1)$ & & 0.69 \\
\hline LDL-cholesterol (mg/dL) & $71.3(24.7)$ & & 22.7 & 163.8 & $70.6(22.9)$ & & $72.1(26.9)$ & & 0.71 \\
\hline Blood Cd ( $\mu \mathrm{g} / \mathrm{L})$ & $0.94(1.07)$ & $0.61(0.7)$ & 0.01 & 5.96 & & $0.61(-0.99)$ & & $0.59(-0.51)$ & 0.6 \\
\hline \multicolumn{10}{|c|}{ Carotid intima-media thickness (CIMT) } \\
\hline $\begin{array}{l}\text { Common carotid artery (CCA) } \\
(\mathrm{mm})\end{array}$ & $0.049(0.007)$ & & 0.033 & 0.07 & $0.052(0.006)$ & & $0.045(0.007)$ & & $<0.001$ \\
\hline $\begin{array}{l}\text { Internal carotid artery (ICA) } \\
(\mathrm{mm})\end{array}$ & $0.045(0.007)$ & & 0.025 & 0.06 & $0.047(0.006)$ & & $0.042(0.006)$ & & $<0.001$ \\
\hline
\end{tabular}

\# Student's t test, except for Blood Cd where Mann-Whitney U test was used

$S D$ standard deviation, $I Q R$ interquartile range

Table 3 Predictors of CIMT; results of multiple regression analysis by enter method

\begin{tabular}{|c|c|c|c|c|c|c|c|c|}
\hline & \multirow[t]{2}{*}{ Adjusted $\mathrm{R}^{2}$} & \multirow[t]{2}{*}{ Predictors } & \multicolumn{2}{|c|}{ Unstandardized coefficients } & \multirow{2}{*}{$\begin{array}{l}\text { Standardized } \beta \\
\text { coefficient }\end{array}$} & \multicolumn{2}{|l|}{$95 \% \mathrm{Cl}$ for $\beta$} & \multirow[t]{2}{*}{$p$-value } \\
\hline & & & B & Standard error & & Lower bound & Upper bound & \\
\hline \multirow[t]{12}{*}{ CCA IMT $(\mu \mathrm{m})$} & \multirow[t]{12}{*}{0.219} & Constant & 39.367 & 11.538 & & & & 0.001 \\
\hline & & Age (years) & 0.612 & 0.433 & 0.118 & -0.047 & 0.283 & 0.160 \\
\hline & & $\operatorname{Sex}(0=$ male, $1=$ female $)$ & -6.210 & 1.610 & -0.438 & -0.662 & -0.214 & $<0.001$ \\
\hline & & BMI $\left(\mathrm{kg} / \mathrm{m}^{2}\right)$ & 0.160 & 0.128 & 0.099 & -0.058 & 0.256 & 0.214 \\
\hline & & Parental education $^{a}$ & 0.117 & 0.733 & 0.012 & -0.137 & 0.161 & 0.873 \\
\hline & & Exposure to cigarette smoke ${ }^{b}$ & 0.909 & 0.785 & 0.096 & -0.068 & 0.260 & 0.249 \\
\hline & & Systolic BP (mmHg) & 0.047 & 0.045 & 0.097 & -0.087 & 0.281 & 0.297 \\
\hline & & Total cholesterol (mg/dL) & -0.026 & 0.020 & -0.108 & -0.270 & 0.054 & 0.189 \\
\hline & & $\mathrm{HDL}-$ cholesterol (mg/dL) & 0.018 & 0.026 & 0.058 & -0.106 & 0.222 & 0.488 \\
\hline & & Haemoglobin (g/dL) & -0.547 & 0.299 & -0.177 & -0.368 & 0.014 & 0.069 \\
\hline & & Blood glucose (mg/dL) & -0.020 & 0.066 & -0.025 & -0.188 & 0.138 & 0.759 \\
\hline & & In Blood Cd & -0.561 & 0.438 & -0.101 & -0.257 & 0.055 & 0.203 \\
\hline \multirow[t]{12}{*}{ ICA IMT ( $\mu \mathrm{m})$} & \multirow[t]{12}{*}{0.165} & Constant & 43.531 & 11.328 & & & & $<0.001$ \\
\hline & & Age (years) & 0.476 & 0.425 & 0.097 & -0.074 & 0.268 & 0.265 \\
\hline & & $\operatorname{Sex}(0=$ male, $1=$ female $)$ & -7.127 & 1.581 & -0.529 & -0.761 & -0.297 & $<0.001$ \\
\hline & & BMI $\left(k g / m^{2}\right)$ & 0.165 & 0.126 & 0.107 & -0.054 & 0.268 & 0.193 \\
\hline & & Parental education $^{a}$ & -0.287 & 0.720 & -0.031 & -0.185 & 0.123 & 0.691 \\
\hline & & Exposure to cigarette smoke ${ }^{b}$ & -0.912 & 0.771 & -0.101 & -0.270 & 0.068 & 0.239 \\
\hline & & Systolic BP (mmHg) & -0.039 & 0.044 & -0.085 & -0.275 & 0.105 & 0.377 \\
\hline & & Total cholesterol (mg/dL) & 0.008 & 0.019 & 0.035 & -0.131 & 0.201 & 0.681 \\
\hline & & HDL-cholesterol (mg/dL) & -0.005 & 0.026 & -0.016 & -0.176 & 0.147 & 0.852 \\
\hline & & Haemoglobin (g/dL) & -0.463 & 0.294 & -0.158 & -0.356 & 0.040 & 0.117 \\
\hline & & Blood glucose (mg/dL) & 0.045 & 0.065 & 0.058 & -0.106 & 0.223 & 0.483 \\
\hline & & In Blood Cd & -0.289 & 0.430 & -0.055 & -0.217 & 0.107 & 0.503 \\
\hline
\end{tabular}

$B M I$ body mass index, BP blood pressure, $C I$ confidence interval, CIMT carotid intima-medial thickness, CCA common carotid artery, ICA internal carotid artery, IMT intima-medial thickness, In natural log transformed

a 1 =without college education, 2 =college education, 3 = postgraduate education

b $1=$ never, $2=$ sometimes, $3=$ frequently, $4=$ always 


\section{Conclusion}

Blood Cd level is not a predictor of CIMT in young adults living in Padang, Indonesia. Regardless, our results are filling the gap of $\mathrm{Cd}$ biomonitoring data from developing countries.

\section{Limitations}

- Our study is small in size.

- Our study does not reflect the general population.

\section{Supplementary information}

Supplementary information accompanies this paper at https://doi. org/10.1186/s13104-020-05042-0.

Additional file 1: Table S1. Associations of CIMT and blood Cd adjusted with age and sex; results of multiple regression analysis by enter method.

\section{Abbreviations}

BMl: Body mass index; BP: Blood pressure; CCA: Common carotid artery; CDC: The US Center for Disease Control and Prevention; Cl: Confidence interval; CIMT: Carotid intima-media thickness; CVD: Cardiovascular disease; Hb: Hemoglobin; HDL: High density lipoprotein; ICA: Internal carotid artery; ICP-MS: Inductively coupled plasma-mass spectrometry; IDR: Indonesian rupiah; IMT: Intima-media thickness; IQR: Interquartile range; LDL: Low density lipoprotein; LOD: Limit of detection; LOQ: Limit of quantification; SD: Standard deviation.

\section{Acknowledgements}

The authors acknowledge all of the participants of the study for their valuable contributions. The authors also thank Ms. Dita Viviant Sagith and Ms. Aisah Djumadisstsaniah as our research assistants for their immense help in data collection.

\section{Authors' contributions}

$\mathrm{Cl}$ and MR conceived and designed the study protocol. Cl and MR formulated the study proposal and obtained funding. MY and DAR performed the measurement of CIMT. Cl conducted data collection in the field, overall management, data analysis and interpretation and wrote the manuscript. MR, MY, and DAR provided suggestions during the preparation of the manuscript. All authors read and approved the final manuscript.

\section{Funding}

This study was supported by grants from the Ministry of Research, Technology and Higher Education of the Republic of Indonesia (KEMENRISTEKDIKTI, Skema Penelitian Berbasis Kompetensi No. 050/SP2H/LT/DRPM/2018 and Skema Penelitian Dasar No. 051/SP2H/LT/DRPM/2019) to Cl. The funder had no role in the design of the study and collection, analysis, and interpretation of data and in writing the manuscript.

\section{Availability of data and materials}

The dataset generated and/or analyzed during the current study are available from the corresponding author on reasonable request.

\section{Ethics approval and consent to participate}

The research protocol for this study was approved by the Committee of Medical Ethics (Approval No. 350/KEP/FK/2018) of Faculty of Medicine, Andalas University. Thorough explanation of study objectives and protocol were given before the health examinations and written informed consent was obtained from each participant.

\section{Consent for publication}

Not applicable.

\section{Competing interests}

None of the authors had any personal or financial conflict of interests.

\section{Author details}

${ }^{1}$ Department of Pharmacology, Faculty of Medicine, Andalas University, Padang, West Sumatra, Indonesia. ${ }^{2}$ Department of Biology, Faculty of Medicine, Andalas University, Padang, West Sumatra, Indonesia. ${ }^{3}$ Department of Cardiology, Faculty of Medicine, Andalas University, Padang, West Sumatra, Indonesia. ${ }^{4}$ Department of Radiology, Faculty of Medicine, Andalas University, Padang, West Sumatra, Indonesia. ${ }^{5}$ Division of Environmental Toxicology, Department of Pharmacology, Faculty of Medicine, Andalas University, Main Campus at Limau Manis, Gedung A Lantai 1, Pauh, Padang, West Sumatra 25166, Indonesia.

Received: 28 November 2019 Accepted: 25 March 2020 Published online: 06 April 2020

\section{References}

1. Agency for Toxic Substances and Disease Registry (ATSDR). Toxicological Profile for Cadmium. Dept. of Health and Human Services; 2012. http:// www.atsdr.cdc.gov/toxprofiles/tp5.pdf. Accessed 1 Oct 2018.

2. Almenara CCP, Broseghini-Filho GB, Vescovi MVA, Angeli JK, Faria TdO, Stefanon I, et al. Chronic cadmium treatment promotes oxidative stress and endothelial damage in isolated rat aorta. PLoS ONE. 2013; https://doi. org/10.1371/journal.pone.0068418.

3. Messner B, Knoflach M, Seubert A, Ritsch A, Pfaller K, Henderson B, et al. Cadmium is a novel and independent risk factor for early atherosclerosis mechanism and in vivo relevance. Arterioscler Thromb Vasc Biol. 2009:29:1392-8.

4. Barregard L, Sallsten G, Fagerberg B, Borné Y, Persson M, Hedblad B, et al. Blood cadmium levels and incident cardiovascular events during follow-up in a population-based cohort of Swedish adults: the Malmo Diet and Cancer Study. Environ Health Perspect. 2016;124(5):594-600.

5. Myong JP, Kim HR, Jang TW, Lee HE, Koo JW. Association between blood cadmium levels and 10-year coronary heart disease risk in the general Korean population: the Korean National Health and Nutrition Examination Survey 20082010. PLoS ONE. 2014;9(11):e111909.

6. Tellez-Plaza M, Navas-Acien A, Menke A, Crainiceanu CM, PastorBarriuso R, et al. Cadmium exposure and all-cause and cardiovascular mortality in the US general population. Environ Health Perspect. 2012;120(7):1017-22.

7. Cosselman KE, Navas-Acien A, Kaufman JD. Environmental factors in cardiovascular disease. Nat Rev Cardiol. 2015. https://doi.org/10.1038/ nrcardio.2015.152.

8. Pena MSB, Rollins A. Environmental exposures and cardiovascular disease: a challenge for health and development in low- and middle-income countries. Cardiol Clin. 2016;35:71-86.

9. Fagerberg B, Barregard L, Sallsten G, Forsgard N, et al. Cadmium exposure and atherosclerotic carotid plaques-results from the Malmö diet and cancer study. Environ Res. 2015;136:67-74.

10. Bergström G, Fagerberg B, Sallsten G, Lundh T, et al. Is cadmium exposure associated with the burden, vulnerability and rupture of human atherosclerotic plaques? PLoS ONE. 2015;10(3):e0121240. https://doi. org/10.1371/journal.pone.0121240.

11. Hong YM. Atherosclerotic cardiovascular disease beginning in childhood. Korean Circ J. 2007:40:1-9.

12. Gersh BJ, Sliwa K, Mayosi BM, Yusuf S. Novel therapeutic concepts: the epidemic of cardiovascular disease in the developing world: global implications. Eur Heart J. 2010;31:642-8.

13. Knoflach M, Kiechl S, Penz D, Zangerle A, Schmidauer C, Rossmann A, et al. Cardiovascular risk factors and atherosclerosis in young women: atherosclerosis Risk Factors in Female Youngsters (ARFY Study). Stroke. 2009;40:1063-9.

14. Yano Y, Reis JP, Colangelo LA, Shimbo D, Viera AJ, Allen NB, et al. Association of blood pressure classification in young adults using the 2017 American College of Cardiology/American Heart Association Blood Pressure Guideline with cardiovascular events later in life. JAMA. 2018;320(17):1774-82. 
15. Oren A, Vos LE, Uiterwaal CSPM, Grobbee DE, Bots ML. Cardiovascular risk factors and increased carotid intima-media thickness in healthy young adults. Arch Intern Med. 2003;163:1787-92

16. Jarup $L$, Akesson A. Current status of cadmium as an environmental health problem. Toxicol Appl Pharmacol. 2009;238:201-8.

17. Kelishadi R, Askarieh A, Motlagh ME, Tajadini M, Heshmat R, Ardalan $\mathrm{G}$, et al. Association of blood cadmium level with cardiometabolic risk factors and liver enzymes in a nationally representative sample of adolescents: the CASPIAN-III study. J Environ Public Health. 2013. https://doi. org/10.1155/2013/142856.

18. Ilmiawati C, Yoshida T, Itoh T, Nakagi Y, Saijo Y, Sugioka Y, et al. Biomonitoring of mercury, cadmium, and lead exposure in Japanese children: a cross-sectional study. Environ Health Prev Med. 2015;20:18-27.

19. Hecht EM, Arheart K, Lee DJ, Hennekens CH, Hlaing WWM. A cross-sectional survey of cadmium biomarkers and cigarette smoking. Biomarkers. 2016. https://doi.org/10.3109/1354750X.2016.1153717.

20. Fløtre CH, Varsi K, Helm T, Bolann B, Bjørke-Monsen A-L. Predictors of mercury, lead, cadmium and antimony status in Norwegian never-pregnant women of fertile age. PLoS ONE. 2017. https://doi.org/10.1371/journ al.pone.0189169.

21. Jarup L, Berglund M, Elinder CG, et al. Health effects of cadmium exposure a review of the literature and a risk estimate. Scand J Work Environ Health. 1998;24:1-51.

22. World Health Organization (WHO). Safety Evaluation of Certain Food Additives and Contaminants. Seventy-third Report of the Joint FAO/WHO Expert Committee on Food Additives; 2011. http://www.inchem.org/ documents/jecfa/jecmono/v64je01.pdf. Accessed 5 Nov 2018.
23. Abu-Hayyeh S, Sian M, Jones KG, Manuel A, Powell JT. Cadmium accumulation in aortas of smokers. Arterioscler Thromb Vasc Biol. 2001;21:863-7.

24. Pignoli P, Tremoli E, Poli A, Oreste P, Paoletti R. Intimal plus medial thickness of the arterial wall: a direct measurement with ultrasound imaging. Circulation. 1986;74:1399-406.

25. O'Leary DH, Bots ML. Imaging of atherosclerosis: carotid intima-media thickness. Eur Heart J. 2010;31:1682-9.

26. Touboul PJ, Hennerici MG, Meairs S, Adams H, Amarenco P, Bornstein N, et al. Mannheim carotid intima-media thickness consensus (20042006). Cerebrovasc Dis. 2006;23:75-80.

27. Stein JH, Korcarz CE, Hurst RT, Lonn E, Kendall CB, Mohler ER, et al. Use of carotid ultrasound to identify subclinical disease and evaluate cardiovascular risk: a consensus statement from the American Society of Echocardiography Carotid Intima-Media Thickness Task Force endorsed by the Society of Vascular Medicine. J Am Soc Echocardiogr. 2008;21:93-111.

\section{Publisher's Note}

Springer Nature remains neutral with regard to jurisdictional claims in published maps and institutional affiliations.
Ready to submit your research? Choose BMC and benefit from:

- fast, convenient online submission

- thorough peer review by experienced researchers in your field

- rapid publication on acceptance

- support for research data, including large and complex data types

- gold Open Access which fosters wider collaboration and increased citations

- maximum visibility for your research: over $100 \mathrm{M}$ website views per year

At BMC, research is always in progress.

Learn more biomedcentral.com/submissions 